\title{
Imprisoned Womanhood in Nawal El Saadawi's Woman at Point Zero and Tehmina Durrani's Blasphemy: A Comparative Study
}

Pankhuri Singh

Research Scholar

Department of Languages

Faculty of Humanities \& Social Sciences

Integral University

Lucknow, Uttar Pradesh, India

pankhurisingh2815@gmail.com

Dr. Syed Wahaj Mohsin

Associate Professor (Jr.)

Department of Languages

Faculty of Humanities \& Social Sciences

Integral University

Lucknow, Uttar Pradesh, India

swahaj@iul.ac.in

\section{Abstract}

The prism of female writing has expanded itself in the current scenario. Contemporary writers have broken all the shackles of the feudal society and have come forward to make people aware of the ubiquitous and distressing condition of women. The unapologetic and unabashedly realistic portrayal of women bound in the shackles of caste and gender in Tehmina Durrani’s Blasphemy and Nawal El Saadawi’s Woman at Point Zero brings to 
surface some of the major issues concerning women's plight. The issues of captivity, matrimony, violence, subjugation and sexism are delineated with prowess. Blasphemy and Woman at Point Zero through the narratives of their protagonists Heer and Firdaus disclose religious and patriarchal norms as a tool to subjugate and oppress women in an orthodox society. Tehmina Durrani’s Blasphemy depicts how distorted Islamic family code of conduct is thrust upon women compelling them to cohere to fundamental values of wedlock, motherhood, servitude and domesticity. Heer becomes a prisoner in her own haveli after her marriage to Pir Sain. Whereas Nawal El Saadawi in Woman at Point Zero portrays the captive life of Firdaus who is a female prisoner, waiting for her execution. The female characters demonstrate how the social, cultural and political structures are responsible for their captivity, degradation and violation.

The present paper attempts to critically study and draw comparison between the two female protagonists. Heer and Firdaus turn captives in the haveli and prison respectively, but eventually they rip off the fake mask of the society which claims to protect women behind the veil of hypocrisy, strangulating even their basic right to be treated as a human.

Keywords: Imprisoned, subjugation, patriarchy, degradation.

This cage of bones and flesh that holds me prisoner... makes a mockery of me and my desires, destroys me daily.

This House of Clay and Water -Faiqa Mansab

Female subjugation has been a protracted phenomenon across margins. Women have been subjected to marginalization and deprivation in myriad ways. They have also been severely betrayed by their own families. Their suffering finds expression in their discourse and in the literary debates that bring the question of womanhood to the mainstream. The literary contribution of prolific women writers to women's literature has witnessed a giant 
leap in recent decades. In terms of Afro-American literature women writers like Toni Cade Bambara, Alice Walker, Maya Angelou, Toni Morrison and bell hooks (sic) have telescoped realities of a woman's life in a racist and sexist scenario. Women writers from the Middle East like Ahdaf Soueif, Mona Prince, Nawal El Saadawi, Radwa Ashour and from India like Arundhati Roy, Chitra Banerjee Divakaruni, Shashi Deshpande, Kamala Markandaya and Githa Hariharan have added to the corpus of women's literature.

The daily transactions in an orthodox society forbid women from taking any voluntary decision, even if that be for her family. She is expected to submit and witness the pseudo traditions and customs that regulate her betterment and development. Men have often remained ignorant and rejected the secondary position of women in society by establishing patriarchy as a façade. Women's bodies and minds in any traditional and orthodox society are re-colonized by men as a medium to preserve their cultural dogmas. She has always been given regards only for her beauty, as a commodity or as a slave by her parents. Women were regarded as objects of gratification in precolonial times and female sexuality was commodified and sold by various means like the selling of a woman to the highest bidder in marriage.

Tehmina Durrani in her novel Blasphemy presents a similar condition where an extremely innocent, beautiful young girl Heer is married to an aged religious leader Pir Sain. Blasphemy portrays a woman's fight against everything which is contradictory to what Islam stands for. It is an amalgamation of fact and fiction, a combination to mask and shield the victims of religious doctrines, while exposing the powerful religious imposters who are preying on poor and helpless people. Blasphemy begins in medias res and informs the readers about the tragic death of Heer's husband. Taking a retrospective turn, the novel vividly portrays the desires and aspirations of a young girl Heer. She is beautiful, naive and completely unaware of the impending doom. Heer's mother is a perfect example of a woman 
caught up in an orthodox society struggling to survive under the patriarchal rule. She is a widow who is shown to be extremely anxious about the destiny of her daughters.

Early marriage is an only option provided to a girl irrespective of her intellectual ability by her economically weak parents. In the novel Heer is an epitome of endurance and beauty. She sacrifices her desires to marry Ranjha, the boy she loved, because her mother ties her destiny to an aged widower Pir Sain. Durrani offers ample guidelines to expose the ills of the society which transforms the body of a young girl into a site of oppression and exploitation through early marriage. Heer's mother finds her marriage as a possibility to rebuild her social status after the death of her husband. She does not consider education as a necessity for her daughter, and when Heer shows her preference for higher education, she furiously retorts, "You must carry your share of responsibility towards your sisters and brother. You are fifteen years old, you can't sit at home forever. . . . Besides, I don't have the money to educate you" (Blasphemy 25). The fear of toxic opinions of the people around Heer's family forced her mother to behave in a selfish way and treat her daughter as a sacrificial lamb. Class consciousness and quest for social escalation is an important theme. In Blasphemy, Heer's mother puts an end to all arguments related to her marriage. Heer like any other girl is taught from the beginning to endure endlessly, but always remain subservient to the dictates of her husband. The idea of a happy, blissful married life seems bizarre to her as she narrates about her first night, "Did I sleep that night or was it some kind of death?" (39). Heer is assaulted by Pir Sain, an experience which haunts her for many years. Heer enters the Haveli, her husband's abode where she is haunted by a sensation of claustrophobia, trapped in the cage of enormous riches, clothes and jewellery. The first public beating of Heer by her husband as she violates the rule of greeting a seven year old boy without a veil reconfirms that she has entered a prison. The rules of Haveli are stern, and Pir Sain demands 
absolute obedience. For years Heer is assaulted, beaten, exploited and held captive in the haveli. The religious facade of Pir Sain allows him to rule over a women's body.

A classic example of how marriages reduce women to mere objects is evident in Nawal El Saadawi's Woman at Point Zero. Nawal El Saadawi is an Egyptian novelist, psychiatrist and a celebrated activist known for her unflinching courage in portraying the enervate and exploited life of Egyptian women. Recognized as "Simone de Beauvoir" of the Arab World, Nawal El Saadawi plunges into the abysmal plight of women in an ultraconservative society. Saadawi in her novels vividly portrays the malicious practices of female genital mutilation, female circumcision, incest, prostitution, self- alienation and gender inequality. She narrates, analyzes and questions the complicity of the subjugation not only of individuals and communities, but also of religious and political bodies, to objectify and commodify women in the Arab world. Saadawi in her novel Woman at Point Zero strives to portray the influence of orthodox patriarchial laws and erroneous assumption of religious scripts on the Egyptian society. The protagonist of the novel suffers extensively under the decrees of men, but she finally matures into a fearless woman who has nothing to lose. In Woman at Point Zero, Nawal El Saadawi outlines her experiences as an Egyptian psychiatrist, researching upon the imprisonment and its psychological influences on female prisoners. Saadawi states in the introduction of her novel that while she was conducting her research in Qanatir Prison, she had no thought of undergoing such extensive transformation. During her visits she comes across a female prisoner who is sentenced to death for killing a man. The female protagonist named Firdaus stands on the verge of execution, but does not beg for mercy. While the psychiatrist desperately requests to meet Firdaus, she simply repudiates her proposal.

A day before her execution, Firdaus agrees to meet the psychiatrist. She commands her to listen to her without directing any questions. The novel explores the tormented and 
deeply anguished life of Firdaus, who was exploited by every single man who came for her help. Firdaus tells that her childhood was damaged due to poverty. As narrated by Firdaus, "With my secondary school certificate and suppressed desires I belonged to the 'middle class'. By birth I was lower class" (WPZ 10). She grew witnessing her father beating her mother while she remained completely subservient to his commands. Firdaus has to undergo genital mutilation that eventually rips her off from experiencing her sexuality. After the demise of her parents, Firdaus is sent to her Uncle who lives in Cairo. Originally she is allowed to study and pursue education, but eventually after the marriage of her uncle, Firdaus is traumatized. Her aunt decides to get her married to Sheikh Mahmoud, who is sixty years old and has facial deformity. Despite her denial she is married to the Sheikh where her life becomes dismal.

The obnoxious sexist socio-cultural practices backed or permitted in Egypt by both distorted religious laws and rituals destroy the life of the protagonist. As a commodity in the name of marriage Firdaus is sold into sexual slavery. She is mistreated and her body is physically and sexually abused. This sort of dehumanizing exploitation in marriage is traceable to women's exploitation. For some people, particularly those who think that patriarchal traditions are natural and unchangeable the payment of the bride price or dowry makes for law and order and gives marriage the deserved honour. But parents and guardians exploited this custom and subjected their daughters as objects not as living beings. A woman does not find asylum even in secure surroundings like her home. In words of Saadawi, “A home may become prison or exile or grave. I am more free when I am homeless, familyless, identityless, nameless, creedless, classless, raceless and genderless" (The Essential xiii).

Even under extreme repression the growing scope of feminist writing by women from orthodox societies pose a significant challenge to the hegemonic male influence.Tehmina Durrani occupies a prominent position among those contemporary women authors in Pakistan 
who are constantly engaged in raising their voices against the relentless marginalization of women and against the vicious patriarchal systems of society. Writers like Faiqa Mansab, Kamila Shamsie, Fatima Bhutto and Sanam Maher have contributed to the body of literature and enriched it. Women's status in Pakistan differs greatly across various ethnic groups, regions and rural-urban divide due to unequal social conditions, poverty, lack of education and economic deprivation. Men have taken undue advantage of their rights by forcing women to remain in purdah. This practice is strictly monitored by men to ensure smooth functioning of male hegemony. Heer masters the art of swallowing her pain and eventually understands her status in the house.

In Blasphemy, the haveli acts as a prison for Heer where she is repeatedly assaulted and turned into a prostitute on the dictates of her husband. She bears children which strengthens her position in the haveli, but behind the dark walls of the haveli Pir Sain turns her into Piyari, a whore from the city. In Woman at Point Zero, Firdaus is captivated in the Qanatir prison for murdering Marzouk, a pimp. She narrates her story to the psychiatrist who visits the prison to study the condition of female prisoners and impact of neurosis. She narrates her journey of turning into a high-class prostitute after running away from her husband. Firdaus' conviction that a prostitute has more worth, is more valued, and is wiser than other women, that a prostitute is entirely autonomous, free from oppression, marriage or love is a misconception and a negative claim borne of wrath towards men and misandry. Firdaus explains how she was held captive first by her husband and later by Bayoumi who turns her into a sex-slave.

Both the protagonists are captivated by the men in control. While Heer is imprisoned in the gothic haveli where her most reliable relationships turn blind to her agony, Firdaus is trapped in a state-sponsored prison. Incest was so common in the family of Pir that any action to prevent it seemed to be a major crime. Pir Sain tries to assault her own daughter Guppi. 
Heer sacrifices an orphan to save her own daughter from the list of Pir Sain. When Pir Sain introduces her own wife as a prostitute from city, Heer asks herself an existential question about selfhood. Staring into mirror she realizes that she has been dishonored by her own husband, "He had spent me without replenishing anything" (Blasphemy 148). Her body is distorted but intellectual energy and determination overcome a woman's inherent biological inferiority. Her body keeps surrendering day after day and the spirit continues to rebel as she looks for a moment of peace. She suffers perpetual torment and abuse at the hands of her husband and after his death at the hands of her own son, who in every way imitates his father. She feels trapped as she affirms that, "I was lost in a realm where space and time were not a concept. ..." (153). This really is a prototype of the social status of women, without their identity. She fights back and discloses the blasphemous sins of Pir to the people. She does not stop until the secret of her identity is revealed. The female protagonists undergo physical, emotional and mental trauma throughout their journey until they decide to break free from the shackles of patriarchal society and direct their lives towards happiness. Despite the torment that the male dominated society and the patriarchial setup bring upon them, the women strive to maintain a strong will and fight back with courage.

In Woman at Point Zero Firdaus is deceived by every man she encounters throughout her journey. Deluded by resentment and rage, Firdaus luxuriates in fatalism and weird reasoning. Prostitution is seen by her as a protest against patriarchal subjugation and double standards. She sees herself as having some freedom which other women cannot reach. She sees herself as "a very successful prostitute" (WPZ 97). Men control politics and eventually the fate of prostitutes in a world where this profession is considered illegal. She meets a pimp Marzouk, who seems to have more connections and influence in society than her. Firdaus is controlled by the demands of Marzouk as she realizes that her profession involves power contestation, and he confiscates the larger part of her earnings. He assaults her, exploits her 
and makes her a captive of his demands. She finally realizes that idea of living an independent life by being a high class prostitute was nothing more than a delusion. She realized, "I was nothing but a body machine working day and night. ..." (103). Firdaus finally decides to leave prostitution with this new knowledge, take her academic credentials and look for a career, but her pimp claims that she has no right to choose what kind of job she would do, saying that as a prostitute she was a slave who had forfeited her independence, dignity and honour. Through beating her he attempts to subdue her but she eventually surfaces. She kills her pimp and breaks free the shackles of the male-hegemony that had deprived her of her rights. In Woman at Point Zero the protagonist anticipates death as an act of grace and dignity that guaranteed her complete liberty, whereas in Blasphemy the protagonist stages her death to escape real death and attains ultimate freedom.

Tehmina Durrani and Nawal El Saadawi demonstrate that if economic dependency and gender inequality give a woman a subordinate status and make her helpless then prostitution further deteriorates their subordinate status and deprive them of their integrity, social esteem and feminity. The novels Woman at Point Zero and Blasphemy give an account of the struggles and trials that women confront which ultimately makes them stand against the androgynous world and hope for a better future. Their endeavour to find solace and their constant struggle in a society dominated by men brings them together and cements their bonds of female sorority. Though both the female protagonists in the novels belong to disparate cultures, yet both end up in the same derogatory profession. Both women are initially different, but as the novel progresses they unite in their motives to find their voice.

Contemporary female writers are constantly fighting against phallogocentric literary discourse. Women across the globe are being encouraged to write their stories and articulate their predicament. Tehmina Durrani and Nawal El Saadawi have portrayed women who are victims of the societal evils and gender inequality. These women eventually rise from their 
docile and weak status to reclaim their identity and register their agony. These women novelists from different regions of the globe have articulated the realities of the lives that women confront. They have focused on incarceration and detention of women by different methods and for different motives. The women in these novels fight their way to the ultimate ownership of their bodies and voice. 


\section{Works Cited}

Durrani, Tehmina. Blasphemy: A Novel. New Delhi: Penguin, 1999. Print.

El Saadawi, Nawal. Woman at Point Zero. Trans. Sherif Hatata.1983. London: Zed Books, 2007. Print.

Horst, Adele Newson., ed. Preface. The Essential Nawal El Saadawi: A Reader. New York: Zed Books, 2010. xi-xvii. Print.

Mansab, Faiqa. This House of Clay and Water. India: Penguin Random House, 2017. Print. 